\title{
IAMJ
}

INTERNATIONAL

AYURVEDIC

MEDICAL JOURNAL

Review Article

ISSN: 2320-5091

Impact Factor: 6.719

\section{AN INSIGHT INTO SICK BUILDING SYNDROME THROUGH AYURVEDA - A REVIEW ARTICLE}

\section{$\underline{\text { Anagha Narayanan }}^{1}, \underline{\text { Susheel Shetty }}^{2}$}

${ }^{1}$ III ${ }^{\text {rd }}$ Year P.G. Scholar, ${ }^{2}$ Guide, Professor and HOD

Dept of P.G. Studies in Kayachikitsa,

Alva's Ayurveda Medical College, Moodbidri, Dakshina Kannada - 574227, Karnataka, India

Corresponding Author: anunavarang4@gmail.com

\section{https://doi.org/10.46607/iamj3209082021}

(Published Online: August 2021)

Open Access

(C) International Ayurvedic Medical Journal, India 2021

Article Received: 21/07//2021 Peer Reviewed: 01/08/2021 Accepted for Publication: 02/08/2021

\section{Check for updates}

\begin{abstract}
The purpose of this paper is to discuss the causes, consequences, and solutions for sick building syndrome (SBS). The approach taken is to evaluate and analyse the causes and symptoms of SBS from various literature and to give it a possible Ayurvedic correlation. The review's findings reveal the effects of SBS in terms of the variety of medical symptoms experienced, personnel or human resource concerns, and economic impacts. The benefit of the paper is that it provides a comprehensive understanding of SBS from both modern and Ayurvedic perspectives by providing full information on its causation, preventive strategies, and symptomatic management using Ayurvedic principles.
\end{abstract}

Keywords: Sick building syndrome, consequences, medical symptoms, ayurvedic principles

\section{INTRODUCTION}

Sick building syndrome (SBS) is "a syndrome of complaints encompassing nonspecific feeling of malaise, the onset of which relates to occupancy of certain buildings as defined by the World Health Organization. "1 SBS symptoms are common in the general population, but it is the pattern in which they manifest that contributes to the diagnosis of SBS. Some may claim that the symptoms of SBS are minimal because no longterm physical harm has been reported, and the symptoms usually go away quickly 
once the affected individual leaves the affected building ${ }^{2}$. However, for individuals who are affected at work, these symptoms are not insignificant. SBS has the potential to have many further consequences like reduced productivity, staff absenteeism due to illness, reduced overtime, and increased staff turnover. Even though the cause effect relations are unclear it is possible to remedy buildings with SBS problems, and for new buildings, the chances of avoiding SBS problems are also good ${ }^{3}$ but some of the impacted buildings may require expensive and dramatic remediation work, such as the replacement of air conditioning systems, windows, and furnishings. However, for some structures, demolition may be the only or most effective option. Hence, it makes it clear that prevention is unarguably better than cure. In Ayurveda, there is no direct reference for SBS and its treatment, but Acharya Susrutha has stated that Nidana parivarjana (avoidance of causative factors) is the primary and fundamental treatment concept for any ailment anywhere in the world, which can be incorporated here. Implying that abstinence from disease causing factors can treat the disease ${ }^{4}$. As a result, the purpose of this work is to analyze SBS and explain its causes, symptoms, management, and preventive aspect and to explain it in terms of Abhisangaja jwara (Fever caused by the affliction of passion, grief etc) as defined in Ayurvedic science.

Aim: To clear the ambiguity of understanding the disease sick building syndrome

\section{Objectives}

To analytically compare sick building syndrome with Abhisangaja jwara.

\section{MATERIALS AND METHODS}

Materials related to Sick building syndrome and Abhisangaja jwara are collected from Ayurvedic text and textbooks of modern medicine respectively. The indexed and nonindexed

Journals were also referred to collect the required information regarding the relevant matter.

\section{Symptoms}

Irritated, dry, or watering eyes, irritated, runny or blocked nose, dry or sore throat, dryness, itching or irritation of the skin, occasionally with a rash, less specific symptoms include headache, lethargy, dizziness, fatigue, irritability and poor concentration. Typically, several of these symptoms are experienced simultaneously and they are often accompanied by complaints about stuffiness, poor air, dry air, noise, light, or temperatures which are too hot or too cold.

\section{Risk factors of SBS.}

Risk factors can be categorised into personal, workrelated activities and building factors. Atopic pathologies like allergic rhinitis, bronchial asthma, eczema etc can be personal risk factors. Work related activities like Work stress, more time spent at work, Lower job status and pay can make the employees at work at risk of developing SBS. Building factors like poor ventilation, inadequate maintenance or recent renovation, poor standards of cleanliness in the working place, humidity, high temperature, improper maintenance of HVAC

(Heaters, ventilators, and air conditioners) are also major risk factors for $\mathrm{SBS}^{3}$.

\section{Aetiology}

The following are some of the factors that might be primarily responsible for SBS:

\section{Chemical contaminants ${ }^{5}$ :}

From outdoor sources: Motor vehicle exhaust, building exhausts (bathrooms and kitchens) can enter the building through poorly located air intake vents, windows and other openings and make the interior of the building contaminated if it is not properly ventilated. Byproducts of combustion can enter a building from a nearby garage. Radon can seep through the foundation of the building and gets trapped in improperly ventilated rooms. Formaldehyde, asbestos, dust, and lead paint can enter through poorly located air intake vents and other openings.

From indoor sources: VOC (Volatile organic compounds) are the most common contaminant inside the building. The main sources of VOC are adhesives, photocopy machines, manufactured wood products, pesticides, cleaning agents, etc. Tobacco smoke, combustion byproducts from the stove, synthetic fragrances in personal care products or cleaning products also contribute to the contamination. Even the carpets used in the offices and residential buildings can 
be an indoor pollutant the synthetic carpets are treated with perfluorinated chemicals to make them stain and waterproof, inhalation of these chemicals can also be a cause for developing SBS and some can even be carcinogenic.

\section{Biological contaminants ${ }^{5}$ :}

The biological contaminants include pollen, bacteria, viruses, moulds etc. These contaminants can breed in stagnant water in humidifiers, drainpipes or on ceiling tiles, insulation, carpets etc. Even animal dander, bird droppings etc can be a source of biological contaminants.

\section{Inadequate ventilation:}

Malfunctioning heating, ventilation, and airconditioning systems (HVAC systems) also increase indoor air pollution. To have an acceptable indoor air quality (IAQ) with minimum energy consumption, The American Society of Heating, Refrigeration and Air Conditioning Engineers (ASHRAE) recently revised ventilation standards to a minimum outdoor airflow rate of $15 \mathrm{cfm} /$ person to avoid the problems related to inadequate ventilation. The standards are $20 \mathrm{cfm} /$ person in office spaces and $60 \mathrm{cfm} /$ person in smoking lounges5. Poor design and construction of buildings with a greater number of offices cramped in a building to increase the salable area also contribute to inadequate ventilation.

\section{Psychological factors}

Excessive work stress or dissatisfaction, poor interpersonal relationships and poor communication are often seen to be associated with SBS $^{6}$.

\section{Poor and inappropriate lighting with absence of sunlight}

The symptoms of SBS are commonly seen in people with clerical jobs than in people with managerial jobs because professionals or managers have better working conditions. The symptoms are more common in females than in males probably because more females are in secretarial jobs, they are more aware of their health, or a lesser dose of pollutants is required to manifest the effects ${ }^{7}$. The symptoms are more common in airconditioned buildings than in naturally ventilated buildings and are more common in a public sector building than in a private sector building

\section{Electromagnetic radiation}

Sources include Smartphones, smartwatches, radios, electric blankets, TV and other electrical appliances, Charging units for mobile phones, cordless electronic devices, Security systems control panels and house wiring, power lines ${ }^{8}$.

\section{Investigations ${ }^{9}$}

1. Evaluating the IAQ (indoor air quality) and identifying the contaminant by air sampling.

2. Establishing a cause-and-effect relationship between symptoms and IAQ.

3. Identifying the cause of the complaints so that appropriate corrective measures can be initiated.

4. Conducting a 'walkthrough' inspection of the problems areas and collecting information on the following:

- The Occupants,

- HVAC Systems for pollution pathways and

- Possible contamination sources

\section{Prevention and control ${ }^{10}$ :}

1. Increase the ventilation rates and air distribution.

2. Removal or modification of the pollutant source can be carried out by routine maintenance of HVAC systems, replacing waterstained ceiling tiles and carpets, using stone etc. Allowing time for building material in new areas to off gas pollutants before occupancy and smoking restrictions are some measures that can be used.

3. Air cleaning can be a useful addition to control air pollution.

4. Education and communication are important parts of any air quality management programme to work more effectively and efficiently to prevent and solve health problems.

5. Legislation

- Banning smoking in the workplace or restricting smoking to designated well ventilated areas away from the work stations and creating no smoking zones with the help of laws. In some European countries, workers have a statutory right to be involved with the employer's plans for changes in the workplace.

6. Research ${ }^{11}$

A field of study originating in Germany called Bau 
Biologie or Building biology has been initiated. The principles of Building biology are as follows:

Site status: The building site should be geologically undisturbed.

Construction concepts: Natural, unadulterated, and nontoxic building materials should be used.

\section{Interiors}

Lighting and colour must mix well with the surroundings and not jar the senses, man made electromagnetic radiation must be reduced as much as possible, interiors should be done by using natural materials without toxic content.

\section{AYURVEDIC CORRELATION:}

Acharya Caraka in sutrasthana has told about three types of diseases i.e. Nija, Agantuja and Manasa among that Agantuja roga (exogenous disease) ${ }^{12}$ is said to be caused due to Bhutha (Invisible organisms or germs), Visha (Poisonous substances), Vayu
(Wind), and Agni (Fire). Similarly, in Jwara Chikitsa adhyaya (Treatment for fever) Acharya Caraka has mentioned Agantuja Jwara (Fever caused by exogenous factors) especially Abhishangaja Jwara ${ }^{13}$ which may be caused by the affliction of Kama (passion), Shoka (grief), Bhaya (fear), Krodha (anger) and Bhutha (invisible organisms or germs). Some acharyas opine that the Jwara (fever) caused by the contact of the poisonous air of the toxic plants and other such toxins is called Abhisangaja Jwara. These factors can be related to the etiological factors of SBS like chemical contaminants (Visha), biological contaminants (Bhutha), psychological factors (Kama, Krodha, Bhaya) and inadequate ventilation (Visha vriksha anila). Also, certain lakshanas mentioned in Abhisangaja Jwara are comparable with the symptoms explained in Sick Building Syndrome.

Table 1: Showing similarities in Sick Building Syndrome and Abhisangaja Jwara:

\begin{tabular}{|c|c|c|}
\hline Symptoms of SBS ${ }^{14}$ & $\begin{array}{l}\text { Lakshanas of Abhisangaja } \\
\text { Jwara (Ca. Chi) })^{15}\end{array}$ & Lakshanas of Abhisangaja Jwara (A.H. Ni) ${ }^{16}$ \\
\hline $\begin{array}{l}\text { Difficulty in concentrating, burning } \\
\text { sensation, shortness of breath }\end{array}$ & Kama Jwara Swasa Bahula & Kama Jwara Daha, Dhi Dhrithi Kshaya \\
\hline Watering of eyes & Shoka Bhashpa Bahula & \\
\hline Headache & & Krodha Shiroruk \\
\hline $\begin{array}{l}\text { Fainting, eye, nose or throat } \\
\text { irritation, dry or itchy skin }\end{array}$ & Visha Murcha, Glani & $\begin{array}{l}\text { Visha Murcha, Aasya } \\
\text { Shyavata, Daha }\end{array}$ \\
\hline Dizziness, nausea, sneezing & & Oushadhi Gandha Murcha, Vamathu, Kshava \\
\hline
\end{tabular}

\section{Probable ayurvedic management:}

Nidana Parivarjana: Nidana parivarjanam i.e abstinence from the disease-causing factors can treat any disease. For e.g., Polluted air inside an inappropriately ventilated building can be a major cause of SBS, hence, to tackle this situation ventilation rates should be increased and air distribution inside the building should be brought to a level where it can prevent the symptoms of SBS related to lack of ventilation. Air cleaning to remove air pollution, banning smoking in workplaces, removal or modification of the pollutant source can be carried out by adopting measures as explained previously. If possible, the patient is asked to change the building where the symptoms are experienced.

\section{Shodhana (Internal purification)}

Virechana (Purgation) can be done with Avipathi churna or Trivrt lehya or Kalyana gulam 2 teaspoons with hot water on an empty stomach.

\section{Shamana (Mitigation therapy)}

Lakshananusara Chikitsa (Symptomatic treatment) must be adopted along with that Vyadhiksamatva (Immunity) must be increased so that they don't get infectious toxic diseases. If eye irritation is present washing the eyes with Triphala Kashaya or Yashtimadhu Kashaya, skin rashes can be washed with Triphaa Kashaya or Panchavalkala Kashaya. 
Pratimarsha Nasya (Nasal medication) with Anu taila or Sadbindhu taila and Abhyanga (Oil Massage) shall be done daily to increase immunity. For bathing Triphala Kashaya, Eladi churna or Sidharthaka snana churna can be used. Even Rasayana prayoga (Rejuvenating therapy) are highly useful in this condition.

\section{Dhoopana}

Dhoopana (fumigation) has also been mentioned for its antimicrobial and broad spectrum of aesthetic, spiritual, psychological, and medical significance which can be incorporated in the prevention and treatment of Sick Building Syndrome. There are many dhupana dravayas (drugs used for fumigation) that possess the quality to kill the microbes ${ }^{17}$. Various Dravyas used by Acharyas for Dhoopana are Nimba, Guggulu, Sarshapa, Vacha, Haridra, Ghritha, Chandana, Ushira, Ela. All are Agni and Vayu Mahabhuta pradhanaya dravyas which are used for Dhoopana karma.

In Kashayapa Samhitas an entire chapter named DHOOPA KALPA is dedicated to this subject. Dhoopas is widely used in Ayurvedic treatments for various reasons.

1. For sanitization and purification of premises

2. For disinfecting

3. For sterilizing the pots in which medicines are to be stored

4. For repelling the insects, poisonous animals etc.

5. For treating diseases such as Balagraha (infectious pediatric diseases), cold, fever due to Vatadosha, etc.

Yoga's which can be used: Indukantha, Kashaya, Guggulutiktakam Kashaya, Balarishtam, Asvagandarishtam, Shirishasava, Asvagandha Churnam, Vilwadi Gutika, Manasamitra Gutika, Haridra Khanda, Vyaghri Ghritha, Vilwadi Lehya, Chyavanaprasha, Anu Taila, Sadbindu Taila.

\section{CONCLUSION}

There is evidence that, while SBS does not cause major health problems, it does have potentially harmful effects. SBS is not only stressful for those who are suffering from the symptoms, but it gives a negative impact on the economy of the country by causing considerable productivity loss, increased sick leave by the employees and dealing with them takes up a lot of time. Even some of the impacted buildings may require expensive and dramatic remediation work, such as the replacement of air conditioning systems, windows, and furnishings. However, for some structures, demolition may be the only or most effective option. Hence, it makes it clear that prevention is unarguably better than cure. Hence, we can say that as seen in any other diseases nidana parivarjana (avoiding the causative factors) plays an important role in SBS as well. We can symptomatically manage the condition with Ayurvedic medicines which have been mentioned in the classics in the context of Jwara (fever), Kasa (cold), Swasa roga (respiratory diseases) chikitsa and different Rasayana yogas can also be used keeping in mind about nidana parivarjana.

\section{REFERENCES}

1. Rostron, J. Sick building syndrome: A review of causes, consequences, and remedies. J Retail Leisure Property 7, 291-303 (2008).

2. https://www.coa.gov.in/show_

3. Sick Building Syndrome in Public Buildings and Workplaces, Sabah. A, Abdul. Wahab, Sick Building Syndrome from an Architectural Perspective, Springer, First edition, 2011; 372.

4. Acharya Y T. Sushruta Samhita with Nibandhasangraha commentary of Dalhanacharya. Uttara Tantra 1/25. Reprint ed. Varanasi (India): Chaukambha Sanskrit Sansthan; 2010.

5. Indoor Air Facts No. 4 (revised) Sick building syndrome. Available from: http://www.epa.gov/iaq/pubs/sbs.html.

6. S. Prevalence and risk factors of sick building syndrome among office workers, Journal of the Egyptian Public Health Association: August 2013 Volume 88 Issue 2 p 109114.

7. Bauer RM, Greve KW, Besch EL et al, The role of psychological factors in the report of buildingrelated symptoms in sick building syndrome. J Consult Clin Psychol. 1992 Apr;60(2):2139.

8. https://www.researchgate.net/publication/11595398_ Why_do_Women_Suffer_from_Sick_Building_Syndr 
ome_more_often_than_MenSubjective_Higher_Sensit ivity_versus_Objective_Causes

9. Indoor Air Facts No. 4 (revised) Sick building syndrome. Available from: http://www.epa.gov/iaq/pubs/sbs.html.

10. IAQ publications. Sick building syndrome fact sheet indoor air facts no. 4 (Revised) Available from: http://www.epa.gov/iaq/pubs/sub.html29k

11. Joshi SM. The sick building syndrome. Indian J Occup Environ Med. 2008 Aug;12(2):614.

12. Dr Ram Karan Sharma, Dr Vaidya Bhagwan Dash, Charaka Samhitha with English translation, edition reprint 2012, Varanasi, Chowkhamba Sanskrit Series office; Vol III, Sutra Sthana, Chapter 20, Sloka no 3.

13. Dr Ram Karan Sharma, Dr Vaidya Bhagwan Dash, Charaka Samhitha with English translation, edition reprint 2012, Varanasi, Chowkhamba Sanskrit Series office; Vol III, Chikitsa Sthana, Chapter 3, Sloka no 114117.

14. Indoor Air Facts No. 4 (revised) Sick building syndrome. Available from: http://www.epa.gov/iaq/pubs/sbs.html.

15. Dr Ram Karan Sharma, Dr Vaidya Bhagwan Dash, Charaka Samhitha with English translation, edition reprint 2012, Varanasi, Chowkhamba Sanskrit Series office; Vol III, Chikitsa Sthana, Chapter 3, Sloka no 122124.

16. Paradakara HSS, Ashtanga Hrudayam with Sarvanga Sundaram commentary of Arunadutta and Ayurveda Rasayana of Hemadri. Nidana Sthana 2/4042 $10^{\text {th }}$ edition. Varanasi (India): Chaukambha Orientalia; 2011.

17. Conceptual Study on Dhoopana Chikitsa in Kashyap Samhita Bhagyashree Zope, Mahesh Harit, Vinay Pawar, Sudarshan Hande, Journal of Ayurveda and Integrated Medical Sciences (JAIMS), 1: 7378, 2017.

\section{Source of Support: Nil \\ Conflict of Interest: None Declared}

How to cite this URL: Anagha Narayanan \& Susheel Shetty: An Insight Into Sick Building Syndrome Through Ayurveda A Review Article. International Ayurvedic Medical Journal \{online\} 2021 \{cited August 2021\} Available from: http://www.iamj.in/posts/images/upload/1800_1805.pdf 